Competitive Comrades 



\title{
Competitive Comrades
}

Career Incentives and Student

Strategies in China

\author{
SUSAN L. SHIRK
}

UNIVERSITY OF CALIFORNIA PRESS

Berkeley Los Angeles London 
University of California Press

Berkeley and Los Angeles, California

University of California Press, Ltd. London, England

○ 1982 by

The Regents of the University of California Printed in the United States of America

$$
\begin{array}{lllllllll}
1 & 2 & 3 & 4 & 5 & 6 & 7 & 8 & 9
\end{array}
$$

\section{Library of Congress Cataloging in Publication Data}

Shirk, Susan L.

Competitive comrades.

Bibliography: p.

Includes index.

1. Students-China-Political activity.

2. Socialism and youth-China. I. Title.

LA1133.7.S553 371.8'1'091 81-2772

ISBN 0-520-04299-9

AACR2 
For my mother and my father 
